the formation of repressor for the biosynthesis of drug-metabolizing enzymes could not be excluded.

On the other hand, Gurtoo et al. (11) have recently reported that the treatment with aflatoxin modified the apparent Michaclis constant $\left(K_{m}\right)$ for benzpyxien hydroxylase. Since the alteration of Km may nullify the inductive effect of phenobarbital in the present investigation, a possible alteration of apparent $\mathrm{Km}$ for aminopyrine $\mathrm{N}$-demethylation and pentobarbital oxidation by aflatoxin should bc investigated.

Further studies on the both possibilities are now under investigation for elucidating the mechanism of the induction of drug-metabolizing activities of liver microsomes by phenobarbital and will be published in detail in elsewhere.

\title{
RETERENGES
}

1) Wognn, G.N.: Bacteriol. Rev. 30, 460 (1966); 2) Barnes, J.M. And Butler, W.H.: Nature, Lond. 202, 1016 (1964); 3) Clifrord, J.I. and Refs, K.R.: Biochem. J. 102, 65 (1967); 4) Clifford, J.I., Rees, K.R. And Stevens, M.E.M.: Biochem. J. 103, 258 (1967); 5) Wogan, G.N. and Frifdman, M.A.: Archs Biochem. Biophys. 128, 509 (1968); 6) Conney, A.H.: Pharmac, Ret. 19,317 (1967); 7) Kato, R., OshimA, T. And Touiznwa, S.: Jap. J. Pharmac. 18, $356(1968) ; 8)$ Kato, R.: Med. exp. 3, 95 (1960); 9) КАто, R.: unpublished observation; 10) Garren, L.D., Howell, R.R., Tomkins, G.M. and Grocco, R.M.: Proc. nal. Acad. Sci., Wash. 52, 1121 (1964); 11) Gurtoo, H.L., Champbeld, T.C., Webd, R.E. and PlowMA., K.M.: Biochem. Biophys. Res. Comm. 31, $588(1968)$

\section{METRAZOL TEST FOR RAPID SGREENING OF ANTICONVULSANTS}

\author{
A. AHMAD AND B.N. DHAWAN \\ Department of Pharmacology, College of Velerinary Science, Jabalpur and \\ Central Drug Research Inst., Lucknow, India \\ Received for publication May 22, 1969
}

Inspite of the availability of several tests no single screening test is capable of picking up all the active anticonvulsant compounds. In routine screening, thereforc, one is obliged to include at least one threshold raising test and one pattern modifying test. Antagonism of metrazol induced clonic seizures and supramaximal electroshock seizure by drugs effective in petit mal and grand mal epilepsy respectively have been employed as screening tests discovering ncw drugs for these disorders. Goodman et al. (1) and Chen et al. (2) have reported maximal tonic seizure following intravenous administration of metrazol in mice and thcy (1) have also suggested that anticonvulsant tests utilizing tonic cxtensor seizure whcther evoked by metrazol or electroshock yield similar information. Intravenous administration of gradually increasing doses of metrazol in mice produces clonic convulsions followed by terminal tonic extension and death (8). We observed that metrazol could produce these three stages in mice when given subcutaneously in a dose of $100 \mathrm{mg} / \mathrm{kg}$ and diphenylhydantoin blockcd the tonic phase of metrazol seizures (3); such observation has been also mentioned by Toman (4) but detailed investigation is not available (5). The present investigation was, therefore, undertaken to find out if anticonvulsants of various types could be picked up by a single metrazol test and whether these anticonvulsants produced differential effects.

Materials and methods: All cxperiments were coducted on mice of either scx weighing $20-25 \mathrm{~g}$ at room temperature $26 \pm 1^{\circ} \mathrm{C}$. $\Lambda$ fixed dose of $100 \mathrm{mg} / \mathrm{kg}$ of metrazol was injected subcutaneously in 25 mice to record the pattern of seizures. 
The effects of the graded doses of the sodium salts of trimethadione, diphenylhydantoin and phenobarbitone were studied on the responses of metrazol $100 \mathrm{mg} / \mathrm{kg}$, s.c. For comparison activity of the drugs in metrazol scizure threshold (MS $\mathrm{T}$ ), (metrazol $80 \mathrm{mg} / \mathrm{kg}$, s.c.), and supramaximal electroshock seizure (SMES), (48 $\mathrm{mA}, 0.2 \mathrm{sec}$ ), pattern tests were studied according to the method of Swinyard et al. (6). Metrazol (100 or $80 \mathrm{mg} / \mathrm{kg}$, s.c.) or electrical challange was given to the groups of treated mice (10-15 in each group) at the time of the peak effect of the drugs. $\mathrm{PD}_{50}$ (protective dose in 50 per cent of mice) with 95 per cent fiducial limits of these drugs were calculated by probit analysis. Approximate $\mathrm{LD}_{50}$ and $\mathrm{TD}_{50}$ values of these drugs were also obtained.

Results and discussion: Metrazol, in a fixed dose of $100 \mathrm{mg} / \mathrm{kg}$, s.c., consistently produced clonic convulsions followed by terminal tonic extension and death within 15 minutes on an average. A perusal of the results, which has been summarized in Table 1, shows that diphenylhydantoin has blocked only the tonic phase in the metrazol test and has been active in SMES test. It may be noted that its PD $_{50}$ in the two tests is identical. Trimethadione and phenobarbitone prevent all the phascs (clonic, tonic convulsions and death) in metrazol test and are also active in MST and SMES tests. In the case of phenobarbitone also the $\mathrm{PD}_{60}$ values against tonic convulsion in metrazol and SMES tests do not differ significantly. The regression lines of the various drugs for blocking the tonic phase in metrazol test and the activity in SMES test are parallel with a common slope of $6.0 \pm 0.1$ and thereby suggesting a similar mechanism of action. This is further supported by the fact that $\mathrm{PD}_{\mathrm{s} 0}$ values of diphenylhydantoin and phenobarbitone in metrazol and SMES tests are identical. The compounds effective against clonic convulsions in metrazol and MST tests similarly have parallel regression lines therapy suggesting again a common mechanism of action. To see if dipherylhydantoin could block the other phases of metrazol convulsions in larger doses, vcry heavy doses (up to $\mathrm{LD}_{50}$ ) of the drug were administered but they were ineffective. Diphenylhydantoin thus specifically blocked only the tonic phase of the experimentally induced convulsions.

In primary screening, compounds are generally tested for anticonvulsant and other biological activities

TABle 1. Anticonvulsant activity of phenobarbitone, trimethadione and diphenylhydantoin using supramaximal electroshock seizures (SMES), metrazol and metrazol seizure threshold (MST) tests in mice.

\begin{tabular}{|c|c|c|c|c|}
\hline \multirow[b]{2}{*}{ Tests } & & \multicolumn{3}{|c|}{$\mathrm{PD}_{50}(95 \%$ fiducial limits $), \mathrm{mg} / \mathrm{kg}$, oral } \\
\hline & & $\begin{array}{c}\text { Phenobarbitone } \\
\text { sodium }\end{array}$ & Trimethadione & $\begin{array}{c}\text { Diphenylhydantoin } \\
\text { sodium }\end{array}$ \\
\hline \multirow[t]{2}{*}{$\begin{array}{l}\text { SMES test } \\
\quad(48 \mathrm{~mA}, 0.2 \mathrm{sec})\end{array}$} & & $\begin{array}{c}18.7 * \\
(15.2-22.2)\end{array}$ & $\begin{array}{c}864.0 * \\
(727-1022)\end{array}$ & $\begin{array}{c}12.1 * \\
(9.2-14.9)\end{array}$ \\
\hline & Clonic & $\begin{array}{c}38.2 * * \\
(33.0-45.6)\end{array}$ & $\begin{array}{c}571.4^{* *} \\
(507-647)\end{array}$ & $\begin{array}{c}\text { No } \\
\text { protection }\end{array}$ \\
\hline \multirow[t]{2}{*}{$\begin{array}{l}\text { Metrazol test } \\
\quad(100 \mathrm{mg} / \mathrm{kg}, \text { s.c. })\end{array}$} & Tonic & $\begin{array}{c}20.7^{*} \\
(17.2-24.6)\end{array}$ & $\begin{array}{c}498.0 * \\
(436.3-526.0)\end{array}$ & $\begin{array}{c}12.0^{*} \\
(9.7-14.1)\end{array}$ \\
\hline & Death & 26.8 & 459.4 & $\begin{array}{l}\text { No } \\
\text { protection }\end{array}$ \\
\hline $\begin{array}{l}\text { MST test } \\
\quad(80 \mathrm{mg} / \mathrm{kg} \text {, s.o. })\end{array}$ & & $\begin{array}{r}25.3 * * * \\
(18.5-31.6)\end{array}$ & $\begin{array}{c}465.4^{* * * *} \\
(356.0-586.0)\end{array}$ & $\begin{array}{l}\text { No } \\
\text { protection }\end{array}$ \\
\hline $\begin{array}{l}\text { Approx. } \mathrm{LD}_{30} \\
(\mathrm{mg} / \mathrm{kg} / \text { oral })\end{array}$ & & 300 & 2500 & 200 \\
\hline $\begin{array}{l}\text { Approx. } \text { TD }_{50} \\
(\mathrm{mg} / \mathrm{kg} / \text { oral })\end{array}$ & & 50 & 700 & 110 \\
\hline
\end{tabular}

* Regression lines for these had a common slope of $6.0 \pm 0.1$

** Common slope $5.29 \pm 1.3$

*** Common slope $6.32 \pm 1.2$ 
at $1 / 5 \mathrm{LD}_{50}$ dose. It is evident from the results containcd in Table 1 that all the drugs, whether used against petit mal or grand mal epilepsy, have shown activity within this dose range and it is unlikely that an active compound would be missed by metrazol test. Mention may also be made that a potent anticonvulsant compound having diphcnylhydantoin type of activity has been picked up using metrazol ( $100 \mathrm{mg} / \mathrm{kg}$, s.c.) test (3). A routine use of the metrazol test for rapid screening of potential anticonvulsant compounds is, therefore, suggested.

Summary and conclusions: Metrazol, $100 \mathrm{mg} / \mathrm{kg}$, s.c., consistently produced clonic convulsions followed by terminal tonic extension and death in mice. Effects of phenobarbitone, trimsthadione and diphenylhydantoin on these responses of metrazol have been studied and compared with their activity in metrazol seizure threshold (MST) and supramaximal elcctroshock scizurc (SMES) pattern tests. Diphenylhydantoin specifically blocked the extensor phase of metrazol-induced convulsions while trimethadione and phenobarbitone blocked all the phases. Parallel regression lines with respect to the blockade of the extensor tonic phase of metrazol seizure and SMES, and that of the clonic phase in metrazol and MST tests suggest a common mechanism of action. Further, results indicatc that metrazol $(100 \mathrm{mg} / \mathrm{kg}$, s.c.) test is sensitive enough to pick up active compounds of either diphenylhydantoin or trimethadione type.

\title{
REFERENCES
}

1) Goodman, L.S., Grewal, M.S., Brown, W.C. and Swinyard, E.A.: J. Pharmac. exp. Ther. 108, 168 (1953); 2) Chien, G., Bohner, B. and Ensor, C.R.: Proc. Soc. exp. Biol. Med. 87, 334 (1954); 3) Ahmad, A.: Indian J. med. Res. 55, 994 (1967); 4) ToMAN, J.E.P.: Animal and Clinical Pharmacological Techniques in Drug Evaluation, Edited by Nodine And Siegler, p. 348, Year Book Medical Publishers Inc., Chicago (1964); 5) Toman, J.E.P.: Personal communication (1968); 6) Swinyard, E.A., Brown, W.C. and Goodman, L.S.: J. Pharmac. exp. Ther. 106, 319 (1952)

\section{DOUBLE ISOTOPE DERIVATIVE METHOD FOR THE DETERMINA- ION OF NORADRENALINE IN RAT BRAIN}

\author{
YOSHIO AIZAWA AND KENJI YAMADA \\ Department of Pharmacology, Tokyo College of Pharmacy, Shinjuku-ku, Tokyo
}

Received for publication June 2, 1969

This paper describes the double isotope derivative method for the determination of noradrenaline in brain tissue using $p$-toluenesulfonyl chloride ${ }^{-35} \mathrm{~S}$ (tosyl chloride ${ }^{-35} \mathrm{~S}$ ). The basis of this method is the label of noradrenaline by esterification with tosyl chloride- ${ }^{35} \mathrm{~S}$.

Malerials and methods: Tosyl chloride- ${ }^{35} \mathrm{~S}$ was synthesized and purificd in our laboratory (1-3). Noradrenaline in brain tissue was extracted according to the method of Shore and Olin (4). Wistar strain male rats weighing approximately $200 \mathrm{~g}$ wcre sacrificed by decapitation and brains were quickly removed and placed on ice. Approximately one gram of brain was homogenized with two volumes of $0.01 \mathrm{~N} \mathrm{HCl}$. The homogenate was transferred into a $100 \mathrm{ml}$ glass-stoppered flask containing $1.5 \times 10^{\circ} \mathrm{dpm}$ of $d l$-noradrenaline${ }^{3} \mathrm{H}(2,120 \mathrm{mC} / \mathrm{mM})$ and $1.7 \mathrm{~g}$ of solid sodium chloride. Fifteen $\mathrm{ml}$ of $\mathrm{n}$-butanol was added to the flask and shaked continuously for one hour at room temperature. The mixture was centrifuged and a $10 \mathrm{ml}$ aliquot 